\title{
Epigenetic changes in gastrointestinal cancers
}

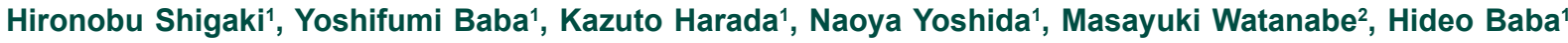 \\ ${ }^{1}$ Department of Gastroenterological Surgery, Graduate School of Medical Science, Kumamoto University, Kumamoto 860-8556, Japan. \\ ${ }^{2}$ Department of Gastroenterological Surgery, Cancer Institute Hospital of Japanese Foundation for Cancer Research, Tokyo 135-8550, Japan.
}

Correspondence to: Dr. Hideo Baba, Department of Gastroenterological Surgery, Graduate School of Medical Science, Kumamoto University, 1-1-1 Honjo, Kumamoto 860-8556, Japan. E-mail: hdobaba@kumamoto-u.ac.jp

\section{A B S T R A C T}

Epigenetic alterations, including DNA methylation, histone modification, loss of genome imprinting, chromatin remodeling and non-coding RNAs, are associated with human carcinogenesis. Among them, DNA methylation is a fundamental epigenetic process to modulate gene expression. In cancer cells, altered DNA methylation includes hypermethylation of site-specific CpG island promoter and global DNA hypo-methylation. Detection of aberrant gene promoter methylation has been applied to the clinic to stratify risk in cancer development, detect early cancer and predict clinical outcomes. Environmental factors associated with carcinogenesis are also significantly related to aberrant DNA methylation. Importantly, epigenetic changes, including altered DNA methylation, are reversible and thus, used as targets for cancer therapy or chemoprevention. An increasing number of recent studies reported DNA methylation level to be a useful biomarker for diagnosis, risk assessment and prognosis prediction for gastrointestinal (GI) cancers. This review summarized the accumulated evidence for clinical application to use aberrant DNA methylation levels in GI cancers, including colorectal, gastric and esophageal cancer.

Key words: Colorectal cancer, DNA methylation, epigenetic alterations, esophageal cancer, gastric cancer

\section{Introduction}

Epigenetics refers to heritable changes in gene expression that, unlike mutations, are not attributable to alterations in genomic DNA sequences. Epigenetic changes, such as DNA methylation, histone modifications, and altered expression of microRNAs, can regulate gene expression through mechanisms other than changes in genomic DNA sequence. Among them, genomic DNA methylation is a major epigenetic mechanism to mediate the $\mathrm{X}$-chromosome inactivation, imprinting and repression of endogenous retroviruses. ${ }^{[1-4]}$ DNA methylation is the covalent post-replicative addition of a methyl group $\left(-\mathrm{CH}_{3}\right)$ to the 5-carbon of the cytosine ring in $\mathrm{CpG}$ dinucleotides. $\mathrm{CpG}$ dinucleotides are non-uniformly distributed throughout the human genome. ${ }^{[2-4]}$ Regions of the genome that are rich in sequences of a cytosine preceding a guanine ( $\mathrm{CpG}$ dinucleotide) are known as $\mathrm{CpG}$ islands, which in particular, exist in the promoter regions of approximately half of all coding genes.

Altered DNA methylation in human cancers includes hypermethylation of site-specific $\mathrm{CpG}$ island promoter and global DNA hypo-methylation. ${ }^{[1-4]}$ DNA methylation in gene promoter $\mathrm{CpG}$ islands results

\begin{tabular}{|l|l|}
\hline \multicolumn{2}{|c|}{ Access this article online } \\
\hline Quick Response Code: & Website: \\
\hline & www.jcmtjournal.com \\
\cline { 2 - 2 } & \\
\hline
\end{tabular}

in its transcriptional inactivity and silence of protein expression. Thus, hypermethylation of a gene promoter is now recognized as a means of silencing tumor suppressor genes with effects similar to those of mutation or allelic loss in the development of cancer or other diseases. ${ }^{[3]}$ Another DNA methylation alteration in human cancer is genome-wide DNA hypo-methylation. ${ }^{[5]}$ Genome-wide DNA hypo-methylation appears to play an important role in genomic instability, leading to cancer development. ${ }^{[6-8]}$ Previous experimental studies demonstrated that DNA hypo-methylation of repetitive sequences, that is, short interspersed transposable elements (SINE or Alu elements) or long interspersed transposable elements (LINEs) may predispose cells to chromosomal defects and rearrangements, resulting in genetic instability. ${ }^{[6]}$ As $L I N E-1$ constitutes a substantial portion (approximately 17\%) in the human genome, levels of LINE-1 methylation are regarded to be surrogate markers for global DNA methylation. ${ }^{[9]}$ Thus, epigenetic regulation of gene expression has emerged as a fundamental way in pathogenesis of numerous malignancies, including cancers of the digestive system.

This is an open access article distributed under the terms of the Creative Commons Attribution-NonCommercial-ShareAlike 3.0 License, which allows others to remix, tweak, and build upon the work non-commercially, as long as the author is credited and the new creations are licensed under the identical terms.

For reprints contact: reprints@ @medknow.com

How to cite this article: Shigaki $\mathrm{H}$, Baba $\mathrm{Y}$, Harada $\mathrm{K}$, Yoshida N, Watanabe M, Baba H. Epigenetic changes in gastrointestinal cancers. $\mathrm{J}$ Cancer Metastasis Treat 2015;1:113-22.

Received: 13-07-2015; Accepted: 01-09-2015. 
In fact, many exciting discoveries in epigenetics have emerged from the study of gastrointestinal (GI) cancers. In this review, we summarized the accumulated evidence supporting the clinical application of DNA methylation level in diagnosis of esophageal, gastric and colorectal cancers.

\section{Altered DNA Methylation in Esophageal Cancer}

Esophageal cancer can be classified into two histological types, esophageal squamous cell carcinoma (ESCC) and esophageal adenocarcinoma (EAC). Their incidences vary notably by geographic distribution. ESCC accounts for approximately $90 \%$ of the esophageal cancers in East Asian countries, ${ }^{[10,11]}$ whereas the highest number of EAC is found in Northern and Western Europe, North America and Oceania. ${ }^{[12]}$ These two subtypes also have different epigenetic alterations. Growing evidence suggests that there is a field of epigenetic changes in esophageal cancer $^{[13-15]}$ by particularly emphasized significance of promoter hypermethylation of 14 specific genes (SFRP1, SFRP2, DCC, APC, p16, p14, APBA1, APBA2, APBA3, CACNA1G, PTGS2, DAPK1, MLH1 and MGMT) in non-cancerous mucosae from ESCC patients $v s$. mucosae from healthy volunteers, ${ }^{[13]}$ indicating that aberrant methylation or these 14 gene promoters in esophageal mucosae is associated with ESCC development. An overview of different previous studies of clinical implications of DNA methylation in esophageal cancer is provided in Table 1. Aberrant promoter methylation of tumor suppressor genes has also been used to predict clinical outcomes following curative ESCC resections. For example, promoter methylation of $A P C$ has been associated with reduced survival of ESCC patients after esophagectomy. ${ }^{[16]}$ Ling et al. ${ }^{[17]}$ showed that $M S H 2$ promoter hypermethylation in circulating tumor DNA was a valuable predictor of disease-free survival of ESCC patients after esophagectomy. Aberrant methylation of FHIT was also reported to be associated with exposure to tobacco smoking and individuals with early-stage ESCC whose tumors exhibited FHIT hypermethylation had poor prognoses. ${ }^{[18]} \mathrm{CDH} 1$ hypermethylation was detected in $14-61 \%$ of ESCC, which was associated with recurrence of early-stage ESCC. ${ }^{[19]}$ Moreover, aberrantly methylated gene promoters were also detected in plasma or sera of ESCC patients. Hibi et al..$^{[20]}$ showed that $p 16$ promoter methylation in ESCC specimens had this same methylation change in their serum DNA in $23 \%$ the of patients, which implied that detection of serum DNA p16 promoter methylation could serve as a tumor marker. However, few studies have addressed or detected DNA hypo-methylation in ESCC. LINE-1 methylation is regarded as a surrogate marker for global DNA methylation. To better understand DNA methylation in ESCC tissues, our group measured their LINE-1 methylation using the pyrosequencing technology. Chronic tobacco smoking and heavy alcohol drinking are established as risk factors for ESCC development. ${ }^{[21-25]}$ LINE-1 hypo-methylation is significantly associated with tobacco smoking, which supports its plausibility as a surrogate marker for an epigenetic field defect. ${ }^{[26]}$ LINE-1 methylation is highly variable among ESCC specimens (25-92\%) and its hypo-methylation is strongly associated with poor ESCC prognosis. ${ }^{[27]}$ Moreover, loss of insulin-like growth factor 2 (IGF2) imprinting has been found in ESCC and loss of $I G F 2$ methylation is associated with shorter survival of patients. ${ }^{[28]}$

Table 1: Association of gene promoter methylation with clinical outcomes of esophageal cancer patients

\begin{tabular}{|c|c|c|c|}
\hline Gene & Histological type & Correlation with clinical outcomes & Reference \\
\hline \multicolumn{4}{|c|}{ DNA hypermethylation } \\
\hline$A P C$ & ESCC & Associated with poor prognosis & {$[16]$} \\
\hline $\mathrm{CDH1}$ & $\mathrm{ESCC}$ & Associated with poor prognosis & [19] \\
\hline p16 & ESCC & Associated with poor prognosis, serum promoter methylation & {$[20,94]$} \\
\hline Claudin-4 & ESCC & Associated with poor prognosis & [95] \\
\hline FHIT & ESCC & Associated with poor prognosis and tobacco/alcohol consumption & {$[18,96]$} \\
\hline Integrin $\alpha 4$ & ESCC & Associated with poor prognosis & [19] \\
\hline$M G M T$ & ESCC & Association with lymph node metastasis & {$[97]$} \\
\hline $\mathrm{MSH} 2$ & ESCC & Associated with poor prognosis & {$[17,98]$} \\
\hline$A K A P 12$ & Barrett/BAC & Progression prediction in Barrett's esophagus & {$[31]$} \\
\hline $\mathrm{CDH} 13$ & Barrett/BAC & Progression prediction in Barrett's esophagus & {$[31]$} \\
\hline p16 & Barrett/BAC & Progression prediction in Barrett's esophagus & {$[31,99]$} \\
\hline$H P P 1$ & Barrett/BAC & Progression prediction in Barrett's esophagus & {$[31,99]$} \\
\hline NELL1 & Barrett/BAC & Progression prediction in Barrett's esophagus & {$[31]$} \\
\hline$R U N X 3$ & Barrett/BAC & Progression prediction in Barrett's esophagus & {$[31,99]$} \\
\hline$S S T$ & Barrett/BAC & Progression prediction in Barrett's esophagus & {$[31]$} \\
\hline$T A C 1$ & Barrett/BAC & Progression prediction in Barrett's esophagus & {$[31]$} \\
\hline \multicolumn{4}{|c|}{ DNA hypomethylation } \\
\hline$I G F 2$ & ESCC & Associated with poor prognosis & {$[28]$} \\
\hline LINE-1 & ESCC & Associated with poor prognosis and tobacco consumption & {$[26,27]$} \\
\hline
\end{tabular}

ESCC: Esophageal squamous cell carcinoma; Barrett/BAC: Barrett's esophageal adenocarcinoma 
In EAC, methylation patterns of promoter $\mathrm{CpG}$ islands in several genes, such as tumor suppressor genes (APC, TIMP3, SFRP1, SFRP2, WIF1, AKAP12, RUNX3, SOCS1 and SOCS3) and DNA repair genes $(M G M T)$, have been reported previously. ${ }^{[29]}$ In Barrett's esophagus, a pre-malignant condition that can lead to EAC development, aberrant DNA methylation has also been shown to occur in promoters of tumor suppressor genes, adhesion molecules and DNA repair genes (AKAP12, APC, CDH13, DAPK1, GPX, GST, MGMT, NELL1, REPRIMO/RPRM, p16, SFRP, SOCS, SST, TAC1, TIMP3 and WIF1). ${ }^{[30]}$ Jin et al. reported that promoter hypermethylation of eight genes (p16, RUNX3, HPP1, NELL1, TAC1, SST, AKAP12 and $C D H 13)$ could predict neoplastic progression risk in Barrett's esophagus. ${ }^{[31]}$ However, in the study of DNA hypo-methylation in Barrett's EAC (BAC), Alvarez et al. reported a predominance of DNA hypo-methylation rather than DNA hyper-methylation in early-stage of BAC carcinogenesis. They also detected DNA hypo-methylation in a series of genes associated with the immune system such as chemokines (CXCL1 and CXCL3). ${ }^{[32]}$

\section{Altered DNA Methylation in Gastric Cancer}

Gastric cancer is the fourth most frequently diagnosed cancer and the second leading cause of cancer-related deaths in the world. ${ }^{[33]}$ Gastric adenocarcinoma accounts for $90-95 \%$ of gastric cancer and has two histological subtypes (intestinal and diffuse) based on microscopic observation and tumor growth patterns, which differ widely in molecular pathogeneses. ${ }^{[34]}$ Nonetheless, epigenetic alterations play important roles in the development of both gastric carcinoma types. Gene promoter methylation has been reported to associate with gastric cancer development, such as $C D K N 2 A, C D K 2 A P 2$, CDH1, MGMT, RASSF1, RUNX3, DLC1, ITGA4, ZIC1, PRDM5, PCDH10, TFPI2, RUNX3, SPINT2, BTG4, SFRP2, hMLH1, DKK-3, TCF4, GRIK2, RAR, CHFR, BNIP3, RASSF1A, LRP1B and SFRP5, promoter of which was more frequently methylated in gastric cancer tissues than those of the corresponding normal gastric tissue. ${ }^{[35,36]}$ Furthermore, promoter methylation of many genes with different biological functions has been associated with the clinicopathological characteristics and prognosis of gastric cancer [Table 2]. ${ }^{[37]}$ Of these genes, promoter hypermethylation of $\mathrm{CDH}^{[38]}$ and $M G M T^{[39,40]}$ was associated with worse outcomes of gastric cancer patients after surgery. However, patients with hypermethylated IGF2 in blood leukocyte DNA reportedly had a significantly better survival rate than those with hypo-methylated IGF2. ${ }^{[41]}$ Additionally, DNA methylation of detected in body fluids that can be obtained non-invasively, such as serum and gastric washes, may have a clinical application for gastric cancer; for example, detection of aberrant DNA methylation of CDH1, DAPK, GSTP1, p15, p16, RAR $\beta, R A S S F 1 A$, RUNX3 and TFPI2 in serum may be a useful biomarker for gastric cancer. ${ }^{[42]}$

Environmental factors also significantly affect DNA methylation. Etiological studies have closely associated two distinct infectious agents, Helicobacter

Table 2: Association of gene promoter methylation with clinical outcomes of gastric cancer

\begin{tabular}{|c|c|c|}
\hline Gene & Correlation with clinical outcomes & References \\
\hline \multicolumn{3}{|c|}{ DNA hypermethylation } \\
\hline BNIP3 & Association with poor prognosis & {$[100,101]$} \\
\hline CACNA2D3 & Correlation with lymph node metastasis & [102] \\
\hline $\mathrm{CDH1}$ & Association with poor prognosis, $H$. pylori infection, and EBV infection & {$[38,46,49-51]$} \\
\hline$D A P K$ & Correlation with cell differentiation, lymph node metastasis & {$[100,103]$} \\
\hline$F L N c$ & Association with poor prognosis & {$[104]$} \\
\hline$G P X 3$ & Correlation with lymph node metastasis & {$[105,106]$} \\
\hline HAI-2/SPINT2 & Correlation with cell differentiation, lymph node metastasis & {$[107]$} \\
\hline HoxD10 & Association with poor prognosis & [108] \\
\hline$L O X$ & Association with poor prognosis and $H$. pylori infection & {$[45]$} \\
\hline$M G M T$ & Association with poor prognosis & {$[103,104,109]$} \\
\hline$M L H 1$ & Association with poor prognosis & {$[104]$} \\
\hline$p 15$ & Association with EBV infection & [49-51] \\
\hline p16 & Association with poor prognosis, H. pylori infection and EBV infection & {$[38,46,49-51,102,104]$} \\
\hline$p 73$ & Association with EBV infection & {$[52]$} \\
\hline PAX6 & Association with poor prognosis & {$[100]$} \\
\hline RASSF1A & Association with poor prognosis & {$[100,103]$} \\
\hline RASSF 2 & Association with poor prognosis & [104] \\
\hline$R U N X 3$ & Correlation with TNM stage and $H$. pylori infection & {$[110,111]$} \\
\hline \multicolumn{3}{|c|}{ DNA hypormetylation } \\
\hline$L I N E-1$ & Association with poor prognosis and $H$. pylori infection & {$[55,56]$} \\
\hline$S U R F$ & Association with poor prognosis & {$[57]$} \\
\hline
\end{tabular}

H. pylori: Helicobacter pylori; EBV: Epstein-Barr virus 
pylori and Epstein-Barr virus (EBV) with gastric carcinogenesis. ${ }^{[43,44]}$ Previous prospective studies showed that $H$. pylori infection had an essential role in gastric carcinogenesis $^{[43]}$ and the mechanisms, underlying gastric carcinogenesis due to $H$. pylori-induced DNA methylation, had been indicated. $H$. pylori infection induced aberrant promoter methylation in tumor-suppressor genes, such as RUNX3, p16, LOX and $C D H 1 .{ }^{[45,46]}$ Furthermore, $I L-1 \beta$ is thought to be especially significant as a specific single-nucleotide polymorphism of $I L-1 \beta$ in association with increases in both gastric cancer risk and incidence. ${ }^{[47,48]} \mathrm{EBV}$ infection occurs at a very early-stage in cancer development and plays an important role in gastric carcinogenesis. Aberrant methylation of tumor suppressor genes, such as CDH1, p15, p16 and p73, is frequently observed in EBV-associated gastric cancer but is less frequently detected in adjacent non-neoplastic mucosa, ${ }^{[49-52]}$ which suggests that aberrant methylation is a critical mechanism of EBV-related gastric tumorigenesis. Regarding the molecular mechanisms underlying host DNA methylation during early-stage EBV infection in gastric epithelium, $L M P 2 A$ expression was upregulated through STAT3 phosphorylation, which further induced DNA methyltransferases during EBV infection. ${ }^{[53]}$

However, few studies addressed or detected DNA hypo-methylation in gastric cancer. In gastric cancer, global genomic hypo-methylation has been found in premalignant stages of the disease. ${ }^{[54]}$ In our previous study that assessed 203 resected gastric cancer specimens, we found gastric cancer tissues had significantly lower LINE-1 methylation levels than that of their matched normal gastric mucosa. LINE-1 hypo-methylation in gastric cancer was also associated with shorter survival of patients. ${ }^{[55]}$ Moreover, LINE-1 hypo-methylation of non-cancerous gastric mucosae in gastric cancer patients significantly correlated with $H$. pylori infection. ${ }^{[56]}$ Hur et al. reported that gastric cancer tissues had conspicuously higher expression of $S U L F 1$ regulated by promoter hypo-methylation than that of the normal mucosa. SULF1 is also an independent prognostic factor, and $\mathrm{LN}$ is a metastasis predictive factor in gastric cancer patients. ${ }^{[57]}$

\section{Altered DNA Methylation in Colorectal Cancer}

Aberrant DNA methylation was reported as an important hallmark of colorectal cancer. Colorectal cancer is a heterogeneous disease and molecularly, it can be classified into three major molecular subtypes, that is, microsatellite instability (MSI), chromosomal instability and $\mathrm{CpG}$ island methylator phenotype (CIMP). ${ }^{[58]}$ In 1999, Baylin and Issa et al. coined the term "CpG island methylator phenotype" or CIMP, in which promoter of tumor suppressor genes was methylated to contribute to tumorigenesis at least in theory through progressive genetic silence, possibly even in the absence of any genetic mutations. ${ }^{[59]}$ According to epigenetic and clinical profiles, primary colorectal cancer is divided into three distinct subclasses, that is, CIMP1, CIMP2 and CIMP-negative. CIMP1 tumor often shows mutations of MSI (80\%) and BRAF (53\%) while CIMP2 tumor often shows $K$-RAS mutation (92\%) but rarely shows MSI or $B R A F$ or TP53 mutations. Non-CIMP tumor has a high frequency of TP53 mutations (71\%). ${ }^{[60]}$ CIMP1 has a favorable prognosis, whereas CIMP2 is associated with poor prognosis. ${ }^{[60]}$ Cancer CIMP status has been assessed as a predictive marker for $5-\mathrm{FU}$ responsiveness. ${ }^{[61]}$

Colorectal cancer with CIMP is distinct from those with chromosomal instability, and there are two forms of nuclear derangement represented alternative pathways for colorectal cancer development, ${ }^{[62,63]}$ which overlap somewhat as hypermethylation can occur in $A P C$ and is part of the chromosomal instability pathway, ${ }^{[64]}$ or in the MLH1 gene, triggering MSI. ${ }^{[65]}$ MLH1 accounts for approximately $40 \%$ of the cases of the hereditary colorectal cancer and Lynch syndrome. ${ }^{[66]}$ Detection of MLH1 methylation is currently used to discriminate between sporadic colorectal cancer with MSI and familial forms (Lynch syndrome). ${ }^{[67]}$ Methylation of $M G M T$ promoter also occurs during colorectal cancer progression in either pathway and may facilitate the accumulation of point mutations as tumors evolve. ${ }^{[65]}$

The $\mathrm{CpG}$ island methylation affects a number of genes in colon cancer, and significance of these epigenetic alterations in colon cancer pathogenesis has been widely reported. ${ }^{[68,69]}$ Hundreds of gene promoters have been found to be aberrantly methylated in the average colorectal cancer genome and their number is ever-growing, including genes of the Wnt signaling pathway such as $A P C, A X I N 2, D K K 1, S F R P 1, S F R P 2$ and $W N T 5 A$, the DNA repair genes $M G M T, h M L H 1$ and $h M L H 2$, cell cycle-related genes such as $p 14, p 15$ and p16, RAS signaling genes RASSF $1 A$ and RASSF $1 B$ and many more. ${ }^{[70,71]}$

Several DNA methylation markers have been proposed as useful early biomarkers for colorectal cancer early detection and prediction of prognosis. For instance, methylation of $\mathrm{MLH1}$ can be detected in colorectal cancer tissue samples ${ }^{[72]}$ or blood ${ }^{[73]}$ to help interpret MSI because its presence helps to exclude diagnosis of Lynch syndrome. The presence of aberrantly methylated SEPT9 (which encodes a GTPase that is involved in dysfunctional cytoskeletal organization) in plasma is a valuable and minimally invasive blood-based polymerase chain reaction test with a sensitivity of almost $70 \%$ and a specificity of $90 \%$ in colorectal cancer detection. ${ }^{[74-78]}$ In fact, an assay that detects hypermethylated SEPT9 is now being commercialized and offered in some parts of Europe to screen colorectal cancer. Moreover, detection of aberrant methylation of vimentin in fecal DNA was reported in colorectal cancer when compared with normal control; ${ }^{[79]}$ the sensitivity and specificity of methylated vimentin for colorectal cancer were $88 \%$ 
and $87 \%$, respectively. ${ }^{[80]}$ Kamimae et al. have recently shown that detection of DNA methylation in mucosal wash fluid from patients undergoing colonoscopy may be a good molecular marker for predicting invasiveness of colorectal tumors. ${ }^{[81]}$

Promoter hypermethylation of MLH1, MGMT and HICl can be detrimental and lead to cancer progression. ${ }^{[82-85]}$ Seven additional genes (TIMP3, CXCL12, ID4, IRF8, CHFR, IGFBP3 and CD109) were frequently methylated in late-stage colorectal cancer and could have a role in colorectal cancer progression and metastasis. ${ }^{[71,86,87]}$ Yi et al. observed that colorectal cancers that have silenced (methylated) genes in the extracellular matrix-remodeling pathway, such as IGFBP3, EVL, $C D 109$ and FLNC, showed worse survival, suggesting that methylation of this pathway-related genes might represent a prognostic signature for colorectal cancer patients. $^{[87]}$ Moreover, hypo-methylation of the IGF2 differentially methylated region in colorectal tumors was associated with poor prognosis. ${ }^{[88]}$ However, all of these possible markers need to be further validated before they are used clinically.

Global hypo-methylation may influence tumor progression by making chromosomes more susceptible to breakage and causing disruption of normal gene structure and function, leading to reactivating previously silenced retrotransposons. ${ }^{[89-91]}$ Most recent research on LINE-1 methylation levels in GI cancers has focused on colorectal cancer; Ogino et al. reported LINE-1 methylation levels widely occurred and approximately normally distributed (range: 23.1-90.3\%) in a cohort of 869 colorectal cancer patients. ${ }^{[92]}$ LINE-1 hypo-methylation was inversely associated to the MSI and CIMP; ${ }^{[92,93]}$ these findings suggest that CIMP/MSI and genomic hypo-methylation represent different pathways in colorectal cancer development. A summary of reported gene methylation in stool, blood and tissue samples of patients with colorectal cancer is shown in Tables 3 and 4.

Table 3: Association of gene promoter methylation with diagnosis of colorectal cancer

\begin{tabular}{|c|c|c|c|}
\hline Gene & Specimen type & Correlation with clinical outcomes & References \\
\hline DNA hypermetylation & & Diagnosis & \\
\hline AGTRI & Stool & Diagnosis of CRC & {$[112]$} \\
\hline$A L X 4$ & Blood & Diagnosis of colorectal adenomas and cancers & [113] \\
\hline$A P C$ & Blood & Diagnosis of CRC & {$[114]$} \\
\hline$B M P 3$ & Stool & Diagnosis of colorectal adenomas and cancers & [115] \\
\hline$B M P 3$ & Tissue & Diagnosis of colorectal adenomas and cancers & [112] \\
\hline CNIP1 & Stool & Diagnosis of CRC & [116] \\
\hline$D A P K$ & Blood & Diagnosis of CRC & {$[117]$} \\
\hline FBN1 & Stool & Diagnosis of CRC & {$[116]$} \\
\hline GATA-5 & Stool & Diagnosis of CRC & {$[118]$} \\
\hline$I G F B P 7$ & Cells & Diagnosis of CRC & [119] \\
\hline$I N A$ & Stool & Diagnosis of CRC & {$[116]$} \\
\hline$M A L$ & Stool & Diagnosis of CRC & {$[116]$} \\
\hline$M G M T$ & Blood & Diagnosis of CRC & {$[114]$} \\
\hline$M L H 1$ & Blood, cells & Diagnosis of sporadic MSI CRC & {$[73]$} \\
\hline$N D R G 4$ & Stool & Diagnosis of CRC & {$[120]$} \\
\hline$N D R G 4$ & Stool & Diagnosis of colorectal adenomas and cancers & {$[115]$} \\
\hline NEUROG1 & Blood & Diagnosis of CRC & {$[121]$} \\
\hline NGFR & Blood & Diagnosis of CRC & {$[74]$} \\
\hline p16 & Blood & Diagnosis of CRC & {$[122]$} \\
\hline$R A S S F 2$ & Stool & Diagnosis of CRC, distinction from gastric cancer & {$[123]$} \\
\hline$R A S S F 2 A$ & Blood & Diagnosis of CRC & {$[114]$} \\
\hline$R U N X 3$ & Blood & Diagnosis of CRC & {$[124]$} \\
\hline$S D C 2$ & Blood & Diagnosis of CRC & {$[125]$} \\
\hline SEPT9 & Blood & Diagnosis of CRC & {$[74,75]$} \\
\hline SFRP2 & Stool, blood, tissue & Diagnosis of CRC, distinction from gastric cancer & {$[123]$} \\
\hline SLIT2 & Stool & Diagnosis of CRC & {$[112]$} \\
\hline$S N C A$ & Stool & Diagnosis of CRC & {$[116]$} \\
\hline$S P G 20$ & Stool & Diagnosis of CRC & {$[116]$} \\
\hline TFPI2 & Stool & Diagnosis of colorectal adenomas and cancers & {$[115]$} \\
\hline$T M E F F 2$ & Blood & Diagnosis of CRC & {$[74]$} \\
\hline Vimentin & Stool, blood & Diagnosis of colorectal adenomas and cancers & {$[126]$} \\
\hline WIF1 & Blood & Diagnosis of CRC & [114] \\
\hline WNT1 & Stool & Diagnosis of CRC & {$[112]$} \\
\hline
\end{tabular}

CRC: Colorectal cancer; MSI: Microsatellite instability 
Table 4: Association of gene promoter methylation with prognosis of colorectal cancer

\begin{tabular}{llll}
\hline Gene & Specimen type & Correlation with clinical outcomes & References \\
\hline DNA hypermetylation & & Prognosis & {$[127]$} \\
$A P C$ & Tissue & Associated with poor prognosis & {$[87]$} \\
$C D 109$ & Tissue & Associated with poor prognosis & {$[87]$} \\
$E V L$ & Tissue & Associated with poor prognosis & {$[87]$} \\
$F L N C$ & Tissue & Associated with poor prognosis & {$[128]$} \\
$H L T F$ & Blood & Associated with poor prognosis & {$[129]$} \\
$H O P X-\beta$ & Tissue & Worse prognosis of stage III CRC & {$[128]$} \\
$H P P 1$ & Blood & Associated with poor prognosis & {$[87]$} \\
$I G F B P 3$ & Tissue & Associated with poor prognosis & {$[130]$} \\
$M L H 1$ & Blood & Associated with favorable prognosis & {$[127]$} \\
$p 16$ & Tissue & Associated with poor prognosis & {$[131]$} \\
$R A S S F 2 A$ & Tissue & Associated with poor prognosis & {$[132]$} \\
$T F P I 2$ & Blood & Associated with poor prognosis & {$[88]$} \\
DNA hypomethylation & & Prognosis & {$[133]$} \\
$I G F 2$ & Tissue & Associated with prognosis & \\
$L I N E-1$ & Tissue & Associated with worse OS & \\
\hline
\end{tabular}

CRC: Colorectal cancer; OS: Overall survival

\section{Conclusion}

In this review, we have summarized the main epigenetic alterations in GI cancer-global DNA hypo-methylation and site-specific $\mathrm{CpG}$ island promoter hypermethylation with clinical characteristics in patients with GI cancers. Epigenetic signatures have a potential usefulness in early diagnosis, screening, monitoring and prediction of prognoses or therapy responses for GI cancer patients. Further investigation in this field would increase our knowledge of epigenetic alterations of GI cancer and help to develop novel therapeutic strategies for GI cancers.

\section{Financial support and sponsorship}

Nil.

\section{Conflicts of interest}

There are no conflicts of interest.

\section{References}

1. Jones PA, Baylin SB. The epigenomics of cancer. Cell 2007; 128:683-92.

2. Portela A, Esteller M. Epigenetic modifications and human disease. Nat Biotechnol 2010;28:1057-68.

3. Rodriguez-Paredes M, Esteller M. Cancer epigenetics reaches mainstream oncology. Nat Med 2011;17:330-9.

4. Taby R, Issa JP. Cancer epigenetics. CA Cancer $J$ Clin 2010;60:376-92.

5. Ehrlich M. DNA hypomethylation in cancer cells. Epigenomics 2009;1:239-59.

6. Gaudet F, Hodgson JG, Eden A, Jackson-Grusby L, Dausman J, Gray JW, Leonhardt H, Jaenisch R. Induction of tumors in mice by genomic hypomethylation. Science 2003;300:489-92.

7. Holm TM, Jackson-Grusby L, Brambrink T, Yamada Y, Rideout WM 3rd, Jaenisch R. Global loss of imprinting leads to widespread tumorigenesis in adult mice. Cancer Cell 2005;8:275-85.

8. Suzuki K, Suzuki I, Leodolter A, Alonso S, Horiuchi S, Yamashita K, Perucho M. Global DNA demethylation in gastrointestinal cancer is age dependent and precedes genomic damage. Cancer Cell 2006;9:199-207.

9. Cordaux R, Batzer MA. The impact of retrotransposons on human genome evolution. Nat Rev Genet 2009;10:691-703.

10. Shibata A, Matsuda T, Ajiki W, Sobue T. Trend in incidence of adenocarcinoma of the esophagus in Japan, 1993-2001. Jpn J Clin Oncol 2008;38:464-8.

11. Enzinger PC, Mayer RJ. Esophageal cancer. $N$ Engl $J$ Med 2003;349:2241-52.

12. Arnold M, Soerjomataram I, Ferlay J, Forman D. Global incidence of oesophageal cancer by histological subtype in 2012. Gut 2015;64:381-7.

13. Ishii T, Murakami J, Notohara K, Cullings HM, Sasamoto H, Kambara T, Shirakawa Y, Naomoto Y, Ouchida M, Shimizu K, Tanaka N, Jass JR, Matsubara N. Oesophageal squamous cell carcinoma may develop within a background of accumulating DNA methylation in normal and dysplastic mucosa. Gut 2007;56:13-9.

14. Ushijima T. Epigenetic field for cancerization. J Biochem Mol Biol 2007;40:142-50

15. Wu DL, Sui FY, Jiang XM, Jiang XH. Methylation in esophageal carcinogenesis. World J Gastroenterol 2006;12:6933-40.

16. Kaz AM, Grady WM. Epigenetic biomarkers in esophageal cancer. Cancer Lett 2014;342:193-9.

17. Ling ZQ, Zhao Q, Zhou SL, Mao WM. MSH2 promoter hypermethylation in circulating tumor DNA is a valuable predictor of disease-free survival for patients with esophageal squamous cell carcinoma. Eur J Surg Oncol 2012;38:326-32.

18. Lee EJ, Lee BB, Kim JW, Shim YM, Hoseok I, Han J, Cho EY, Park J, Kim DH. Aberrant methylation of fragile histidine triad gene is associated with poor prognosis in early stage esophageal squamous cell carcinoma. Eur $J$ Cancer 2006;42:972-80.

19. Lee EJ, Lee BB, Han J, Cho EY, Shim YM, Park J, Kim DH. $\mathrm{CpG}$ island hypermethylation of E-cadherin (CDH1) and integrin alpha4 is associated with recurrence of early stage esophageal squamous cell carcinoma. Int $J$ Cancer 2008;123:2073-9.

20. Hibi K, Taguchi M, Nakayama H, Takase T, Kasai Y, Ito K, Akiyama S, Nakao A. Molecular detection of p16 promoter methylation in the serum of patients with esophageal squamous cell carcinoma. Clin Cancer Res 2001;7:3135-8. 
21. Morita M, Kumashiro R, Kubo N, Nakashima Y, Yoshida R, Yoshinaga K, Saeki H, Emi Y, Kakeji Y, Sakaguchi Y, Toh Y, Maehara Y. Alcohol drinking, cigarette smoking, and the development of squamous cell carcinoma of the esophagus: epidemiology, clinical findings, and prevention. Int $J$ Clin Oncol 2010;15:126-34.

22. Steevens J, Schouten LJ, Goldbohm RA, van den Brandt PA. Alcohol consumption, cigarette smoking and risk of subtypes of oesophageal and gastric cancer: a prospective cohort study. Gut 2010;59:39-48.

23. Tanaka F, Yamamoto K, Suzuki S, Inoue H, Tsurumaru M, Kajiyama Y, Kato H, Igaki H, Furuta K, Fujita H, Tanaka T, Tanaka Y, Kawashima Y, Natsugoe S, Setoyama T, Tokudome S, Mimori K, Haraguchi N, Ishii H, Mori M. Strong interaction between the effects of alcohol consumption and smoking on oesophageal squamous cell carcinoma among individuals with ADH1B and/or ALDH2 risk alleles. Gut 2010;59:1457-64.

24. Yokoyama A, Kumagai Y, Yokoyama T, Omori T, Kato H, Igaki H, Tsujinaka T, Muto M, Yokoyama M, Watanabe $\mathrm{H}$. Health risk appraisal models for mass screening for esophageal and pharyngeal cancer: an endoscopic follow-up study of cancer-free Japanese men. Cancer Epidemiol Biomarkers Prev 2009;18:651-5.

25. Yokoyama A, Omori T, Yokoyama T, Sato Y, Mizukami T, Matsushita S, Higuchi S, Maruyama K, Ishii H, Hibi T. Risk of squamous cell carcinoma of the upper aerodigestive tract in cancer-free alcoholic Japanese men: an endoscopic follow-up study. Cancer Epidemiol Biomarkers Prev 2006;15:2209-15.

26. Shigaki H, Baba $Y$, Watanabe $M$, Iwagami $S$, Miyake $K$, Ishimoto T, Iwatsuki M, Baba H. LINE-1 Hypomethylation in noncancerous esophageal mucosae is associated with smoking history. Ann Surg Oncol2012; doi: 10. 1245/s 10434-012-2488-y.

27. Iwagami S, Baba $Y$, Watanabe $M$, Shigaki $H$, Miyake $K$, Ishimoto T, Iwatsuki M, Sakamaki K, Ohashi Y, Baba H. LINE-1 hypomethylation is associated with a poor prognosis among patients with curatively resected esophageal squamous cell carcinoma. Ann Surg 2013; doi: 10.1097/ SLA.0b013e31826d8602.

28. Murata A, Baba Y, Watanabe M, Shigaki H, Miyake K, Ishimoto $\mathrm{T}$, Iwatsuki $\mathrm{M}$, Iwagami $\mathrm{S}$, Yoshida $\mathrm{N}$, Oki $\mathrm{E}$, Morita M, Nakao M, Baba H. IGF2 DMR0 methylation, loss of imprinting, and patient prognosis in esophageal squamous cell carcinoma. Ann Surg Oncol 2014;21:1166-74.

29. Selaru FM, David S, Meltzer SJ, Hamilton JP. Epigenetic events in gastrointestinal cancer. $\mathrm{Am} J$ Gastroenterol 2009;104:1910-2.

30. Agarwal A, Polineni R, Hussein Z, Vigoda I, Bhagat TD, Bhattacharyya S, Maitra A, Verma A. Role of epigenetic alterations in the pathogenesis of Barrett's esophagus and esophageal adenocarcinoma. Int J Clin Exp Pathol 2012;5:382-96.

31. Jin Z, Cheng Y, Gu W, Zheng Y, Sato F, Mori Y, Olaru AV, Paun BC, Yang J, Kan T, Ito T, Hamilton JP, Selaru FM, Agarwal R, David S, Abraham JM, Wolfsen HC, Wallace MB, Shaheen NJ, Washington K, Wang J, Canto MI, Bhattacharyya A, Nelson MA, Wagner PD, Romero Y, Wang KK, Feng Z, Sampliner RE, Meltzer SJ. A multicenter, double-blinded validation study of methylation biomarkers for progression prediction in Barrett's esophagus. Cancer Res 2009;69:4112-5

32. Alvarez H, Opalinska J, Zhou L, Sohal D, Fazzari MJ, Yu Y, Montagna C, Montgomery EA, Canto M, Dunbar KB, Wang J, Roa JC, Mo Y, Bhagat T, Ramesh KH, Cannizzaro L, Mollenhauer J, Thompson RF, Suzuki M, Meltzer SJ, Melnick A, Greally JM, Maitra A, Verma A. Widespread hypomethylation occurs early and synergizes with gene amplification during esophageal carcinogenesis. PLoS Genet 2011;7:e1001356.

33. Parkin DM, Bray F, Ferlay J, Pisani P. Global cancer statistics, 2002. CA Cancer J Clin 2005;55:74-108.

34. Jinawath N, Furukawa Y, Hasegawa S, Li M, Tsunoda T, Satoh S, Yamaguchi $T$, Imamura $H$, Inoue $M$, Shiozaki $H$, Nakamura Y. Comparison of gene-expression profiles between diffuse- and intestinal-type gastric cancers using a genome-wide cDNA microarray. Oncogene 2004;23:6830-44.

35. Kim TY, Jong HS, Jung Y, Kang GH, Bang YJ. DNA hypermethylation in gastric cancer. Aliment Pharmacol Ther 2004;20 Suppl 1:131-42.

36. Nakamura J, Tanaka T, Kitajima Y, Noshiro H, Miyazaki K. Methylation-mediated gene silencing as biomarkers of gastric cancer: a review. World $J$ Gastroenterol 2014;20:11991-2006.

37. Otani K, Li X, Arakawa T, Chan FK, Yu J. Epigenetic-mediated tumor suppressor genes as diagnostic or prognostic biomarkers in gastric cancer. Expert Rev Mol Diagn 2013;13:445-55.

38. Yu QM, Wang XB, Luo J, Wang S, Fang XH, Yu JL, Ling ZQ. $\mathrm{CDH} 1$ methylation in preoperative peritoneal washes is an independent prognostic factor for gastric cancer. J Surg Oncol 2012;106:765-71.

39. Park TJ, Han SU, Cho YK, Paik WK, Kim YB, Lim IK. Methylation of $\mathrm{O}$ (6)-methylguanine-DNA methyltransferase gene is associated significantly with K-ras mutation, lymph node invasion, tumor staging, and disease free survival in patients with gastric carcinoma. Cancer 2001;92:2760-8.

40. Bae SI, Lee HS, Kim SH, Kim WH. Inactivation of O6-methylguanine-DNA methyltransferase by promoter $\mathrm{CpG}$ island hypermethylation in gastric cancers. $\mathrm{Br} J$ Cancer 2002;86:1888-92

41. Yuasa Y, Nagasaki H, Oze I, Akiyama Y, Yoshida S, Shitara K, Ito $\mathrm{S}$, Hosono $\mathrm{S}$, Watanabe $\mathrm{M}$, Ito $\mathrm{H}$, Tanaka $\mathrm{H}$, Kang $\mathrm{D}$, Pan KF, You WC, Matsuo K. Insulin-like growth factor 2 hypomethylation of blood leukocyte DNA is associated with gastric cancer risk. Int J Cancer 2012;131:2596-603.

42. Qu Y, Dang S, Hou P. Gene methylation in gastric cancer. Clin Chim Acta 2013;424:53-65.

43. Uemura $\mathrm{N}$, Okamoto $\mathrm{S}$, Yamamoto $\mathrm{S}$, Matsumura $\mathrm{N}$, Yamaguchi S, Yamakido M, Taniyama K, Sasaki N, Schlemper RJ. Helicobacter pylori infection and the development of gastric cancer. $N$ Engl J Med 2001;345:784-9.

44. Matsusaka K, Kaneda A, Nagae G, Ushiku T, Kikuchi Y, Hino R, Uozaki H, Seto Y, Takada K, Aburatani H, Fukayama M. Classification of Epstein-Barr virus-positive gastric cancers by definition of DNA methylation epigenotypes. Cancer Res 2011;71:7187-97.

45. Kaneda A, Wakazono K, Tsukamoto T, Watanabe N, Yagi Y, Tatematsu M, Kaminishi M, Sugimura T, Ushijima T. Lysyl oxidase is a tumor suppressor gene inactivated by methylation and loss of heterozygosity in human gastric cancers. Cancer Res 2004;64:6410-5.

46. Ushijima T, Nakajima T, Maekita T. DNA methylation as a marker for the past and future. $J$ Gastroenterol 2006;41:401-7.

47. Chan AO, Chu KM, Huang C, Lam KF, Leung SY, Sun YW, Ko S, Xia HH, Cho CH, Hui WM, Lam SK, Rashid A. Association between Helicobacter pylori infection and interleukin lbeta polymorphism predispose to $\mathrm{CpG}$ island methylation in gastric cancer. Gut 2007;56:595-7.

48. El-Omar EM, Carrington M, Chow WH, McColl KE, Bream JH, Young HA, Herrera J, Lissowska J, Yuan CC, Rothman N, Lanyon G, Martin M, Fraumeni JF Jr, Rabkin CS. Interleukin-1 polymorphisms associated with increased risk of gastric cancer. Nature 2000;404:398-402. 
49. Fukayama M. Epstein-Barr virus and gastric carcinoma. Pathol Int 2010;60:337-50.

50. Fukayama M, Ushiku T. Epstein-Barr virus-associated gastric carcinoma. Pathol Res Pract 2011;207:529-37.

51. Uozaki H, Fukayama M. Epstein-Barr virus and gastric carcinoma-viral carcinogenesis through epigenetic mechanisms. Int J Clin Exp Pathol 2008;1:198-216.

52. Ushiku T, Chong JM, Uozaki H, Hino R, Chang MS, Sudo M, Rani BR, Sakuma K, Nagai H, Fukayama M. p73 gene promoter methylation in Epstein-Barr virus-associated gastric carcinoma. Int J Cancer 2007;120:60-6.

53. Hino R, Uozaki H, Murakami N, Ushiku T, Shinozaki A, Ishikawa S, Morikawa T, Nakaya T, Sakatani T, Takada K, Fukayama M. Activation of DNA methyltransferase 1 by EBV latent membrane protein $2 \mathrm{~A}$ leads to promoter hypermethylation of PTEN gene in gastric carcinoma. Cancer Res 2009;69:2766-74.

54. Jang BG, Kim WH. Molecular pathology of gastric carcinoma. Pathobiology 2011;78:302-10.

55. Shigaki H, Baba Y, Watanabe M, Murata A, Iwagami S, Miyake K, Ishimoto T, Iwatsuki M, Baba H. LINE-1 hypomethylation in gastric cancer, detected by bisulfite pyrosequencing, is associated with poor prognosis. Gastric Cancer 2013;16:480-7.

56. Kosumi K, Baba Y, Ishimoto T, Harada K, Miyake K, Izumi D, Tokunaga R, Murata A, Eto K, Sugihara H, Shigaki H, Iwagami S, Sakamoto Y, Miyamoto Y, Yoshida N, Watanabe M, Komohara Y, Takeya M, Baba H. Relationship between LINE-1 hypomethylation and Helicobacter pylori infection in gastric mucosae. Med Oncol 2015;32:117.

57. Hur K, Han TS, Jung EJ, Yu J, Lee HJ, Kim WH, Goel A, Yang HK. Up-regulated expression of sulfatases (SULF1 and SULF2) as prognostic and metastasis predictive markers in human gastric cancer. J Pathol 2012;228:88-98.

58. Worthley DL, Leggett BA. Colorectal cancer: molecular features and clinical opportunities. Clin Biochem Rev 2010;31:31-8.

59. Toyota M, Ahuja N, Ohe-Toyota M, Herman JG, Baylin SB, Issa JP. CpG island methylator phenotype in colorectal cancer. Proc Natl Acad Sci U S A 1999;96:8681-6.

60. Shen L, Toyota M, Kondo Y, Lin E, Zhang L, Guo Y, Hernandez NS, Chen X, Ahmed S, Konishi K, Hamilton SR, Issa JP. Integrated genetic and epigenetic analysis identifies three different subclasses of colon cancer. Proc Natl Acad Sci US A 2007;104:18654-9.

61. Ide T, Kitajima Y, Ohtaka K, Mitsuno M, Nakafusa Y, Miyazaki K. Expression of the hMLH1 gene is a possible predictor for the clinical response to 5-fluorouracil after a surgical resection in colorectal cancer. Oncol Rep 2008;19:1571-6.

62. Goel A, Arnold CN, Niedzwiecki D, Chang DK, Ricciardiello L, Carethers JM, Dowell JM, Wasserman L, Compton C, Mayer RJ, Bertagnolli MM, Boland CR. Characterization of sporadic colon cancer by patterns of genomic instability. Cancer Res 2003;63:1608-14.

63. Goel A, Nagasaka $\mathrm{T}$, Arnold $\mathrm{CN}$, Inoue $\mathrm{T}$, Hamilton $\mathrm{C}$, Niedzwiecki D, Compton C, Mayer RJ, Goldberg R, Bertagnolli MM, Boland CR. The $\mathrm{CpG}$ island methylator phenotype and chromosomal instability are inversely correlated in sporadic colorectal cancer. Gastroenterology 2007;132:127-38.

64. Arnold CN, Goel A, Niedzwiecki D, Dowell JM, Wasserman L, Compton C, Mayer RJ, Bertagnolli MM, Boland CR. APC promoter hypermethylation contributes to the loss of APC expression in colorectal cancers with allelic loss on 5q. Cancer Biol Ther 2004;3:960-4.
65. Arnold CN, Goel A, Compton C, Marcus V, Niedzwiecki D, Dowell JM, Wasserman L, Inoue T, Mayer RJ, Bertagnolli MM, Boland CR. Evaluation of microsatellite instability, hMLH1 expression and hMLH1 promoter hypermethylation in defining the MSI phenotype of colorectal cancer. Cancer Biol Ther 2004;3:73-8.

66. Boland CR, Goel A. Microsatellite instability in colorectal cancer. Gastroenterology 2010;138:2073-87e3.

67. Bouzourene H, Hutter P, Losi L, Martin P, Benhattar J. Selection of patients with germline MLH1 mutated Lynch syndrome by determination of MLH1 methylation and BRAF mutation. Fam Cancer 2010;9:167-72.

68. Baylin SB, Herman JG. DNA hypermethylation in tumorigenesis: epigenetics joins genetics. Trends Genet 2000;16:168-74.

69. Rashid A, Shen L, Morris JS, Issa JP, Hamilton SR. CpG island methylation in colorectal adenomas. Am J Pathol 2001;159:1129-35.

70. Coppede F. Epigenetic biomarkers of colorectal cancer: focus on DNA methylation. Cancer Lett 2014;342:238-47.

71. Lao VV, Grady WM. Epigenetics and colorectal cancer. Nat Rev Gastroenterol Hepatol 2011;8:686-700.

72. Wang L, Cunningham JM, Winters JL, Guenther JC, French AJ, Boardman LA, Burgart LJ, McDonnell SK, Schaid DJ, Thibodeau SN. BRAF mutations in colon cancer are not likely attributable to defective DNA mismatch repair. Cancer Res 2003;63:5209-12.

73. Grady WM, Rajput A, Lutterbaugh JD, Markowitz SD. Detection of aberrantly methylated hMLH1 promoter DNA in the serum of patients with microsatellite unstable colon cancer. Cancer Res 2001;61:900-2.

74. Lofton-Day C, Model F, Devos T, Tetzner R, Distler J, Schuster M, Song X, Lesche R, Liebenberg V, Ebert M, Molnar B, Grutzmann R, Pilarsky C, Sledziewski A. DNA methylation biomarkers for blood-based colorectal cancer screening. Clin Chem 2008;54:414-23.

75. deVos T, Tetzner R, Model F, Weiss G, Schuster M, Distler J, Steiger KV, Grutzmann R, Pilarsky C, Habermann JK, Fleshner PR, Oubre BM, Day R, Sledziewski AZ, Lofton-Day C. Circulating methylated SEPT9 DNA in plasma is a biomarker for colorectal cancer. Clin Chem 2009;55:1337-46.

76. Grutzmann R, Molnar B, Pilarsky C, Habermann JK, Schlag PM, Saeger HD, Miehlke S, Stolz T, Model F, Roblick UJ, Bruch HP, Koch R, Liebenberg V, Devos T, Song X, Day RH, Sledziewski AZ, Lofton-Day C. Sensitive detection of colorectal cancer in peripheral blood by septin 9 DNA methylation assay. PLoS One 2008;3:e3759.

77. Tanzer M, Balluff B, Distler J, Hale K, Leodolter A, Rocken C, Molnar B, Schmid R, Lofton-Day C, Schuster T, Ebert MP. Performance of epigenetic markers SEPT9 and ALX4 in plasma for detection of colorectal precancerous lesions. PLoS One 2010;5:e9061.

78. Kostin PA, Zakharzhevskaia NB, Generozov EV, Govorun VM, Chernyshov SV, Shchelygin Iu A. Hypermethylation of the CDH1, SEPT9, HLTF and ALX4 genes and their diagnostic significance in colorectal cancer. Vopr Onkol 2010;56:162-8.

79. Chen WD, Han ZJ, Skoletsky J, Olson J, Sah J, Myeroff L, Platzer P, Lu S, Dawson D, Willis J, Pretlow TP, Lutterbaugh J, Kasturi L, Willson JK, Rao JS, Shuber A, Markowitz SD. Detection in fecal DNA of colon cancer-specific methylation of the nonexpressed vimentin gene. J Natl Cancer Inst 2005;97:1124-32.

80. Itzkowitz SH, Jandorf L, Brand R, Rabeneck L, Schroy PC 3rd, Sontag S, Johnson D, Skoletsky J, Durkee K, Markowitz S, 
Shuber A. Improved fecal DNA test for colorectal cancer screening. Clin Gastroenterol Hepatol 2007;5:111-7.

81. Kamimae S, Yamamoto E, Yamano HO, Nojima M, Suzuki H, Ashida M, Hatahira T, Sato A, Kimura T, Yoshikawa K, Harada T, Hayashi S, Takamaru H, Maruyama R, Kai M, Nishiwaki M, Sugai T, Sasaki Y, Tokino T, Shinomura Y, Imai K, Toyota M. Epigenetic alteration of DNA in mucosal wash fluid predicts invasiveness of colorectal tumors. Cancer Prev Res (Phila) 2011;4:674-83.

82. Kane MF, Loda M, Gaida GM, Lipman J, Mishra R, Goldman H, Jessup JM, Kolodner R. Methylation of the hMLH1 promoter correlates with lack of expression of hMLH1 in sporadic colon tumors and mismatch repair-defective human tumor cell lines. Cancer Res 1997;57:808-11.

83. Veigl ML, Kasturi L, Olechnowicz J, Ma AH, Lutterbaugh JD, Periyasamy S, Li GM, Drummond J, Modrich PL, Sedwick WD, Markowitz SD. Biallelic inactivation of hMLH1 by epigenetic gene silencing, a novel mechanism causing human MSI cancers. Proc Natl Acad Sci U S A 1998;95:8698-702.

84. Shin SK, Nagasaka T, Jung BH, Matsubara N, Kim WH, Carethers JM, Boland CR, Goel A. Epigenetic and genetic alterations in Netrin-1 receptors UNC5C and DCC in human colon cancer. Gastroenterology 2007;133:1849-57.

85. Hibi K, Mizukami H, Shirahata A, Goto T, Sakata M, Sanada Y. Aberrant methylation of the netrin-1 receptor genes UNC5C and DCC detected in advanced colorectal cancer. World J Surg 2009;33:1053-7.

86. Tanaka M, Chang P, Li Y, Li D, Overman M, Maru DM, Sethi S, Phillips J, Bland GL, Abbruzzese JL, Eng C. Association of CHFR promoter methylation with disease recurrence in locally advanced colon cancer. Clin Cancer Res 2011;17:4531-40.

87. Yi JM, Dhir M, Van Neste L, Downing SR, Jeschke J, Glockner SC, de Freitas Calmon M, Hooker CM, Funes JM, Boshoff C, Smits KM, van Engeland M, Weijenberg MP, Iacobuzio-Donahue CA, Herman JG, Schuebel KE, Baylin SB, Ahuja N. Genomic and epigenomic integration identifies a prognostic signature in colon cancer. Clin Cancer Res 2011;17:1535-45.

88. Baba Y, Nosho K, Shima K, Huttenhower C, Tanaka N, Hazra A, Giovannucci EL, Fuchs CS, Ogino S. Hypomethylation of the IGF2 DMR in colorectal tumors, detected by bisulfite pyrosequencing, is associated with poor prognosis. Gastroenterology 2010;139:1855-64.

89. Wong JJ, Hawkins NJ, Ward RL. Colorectal cancer: a model for epigenetic tumorigenesis. Gut 2007;56:140-8.

90. Ji W, Hernandez R, Zhang XY, Qu GZ, Frady A, Varela M, Ehrlich M. DNA demethylation and pericentromeric rearrangements of chromosome 1. Mutat Res 1997;379:33-41.

91. Suter CM, Martin DI, Ward RL. Hypomethylation of L1 retrotransposons in colorectal cancer and adjacent normal tissue. Int J Colorectal Dis 2004;19:95-101.

92. Ogino S, Kawasaki T, Nosho K, Ohnishi M, Suemoto Y, Kirkner GJ, Fuchs CS. LINE-1 hypomethylation is inversely associated with microsatellite instability and $\mathrm{CpG}$ island methylator phenotype in colorectal cancer. Int $J$ Cancer 2008;122:2767-73.

93. Estecio MR, Gharibyan V, Shen L, Ibrahim AE, Doshi K, He R, Jelinek J, Yang AS, Yan PS, Huang TH, Tajara EH, Issa JP. LINE-1 hypomethylation in cancer is highly variable and inversely correlated with microsatellite instability. PLoS One 2007;2:e399.

94. Fujiwara S, Noguchi T, Takeno S, Kimura Y, Fumoto S, Kawahara K. Hypermethylation of p16 gene promoter correlates with loss of p16 expression that results in poorer prognosis in esophageal squamous cell carcinomas. Dis Esophagus 2008;21:125-31.

95. Sung CO, Han SY, Kim SH. Low expression of claudin-4 is associated with poor prognosis in esophageal squamous cell carcinoma. Ann Surg Oncol 2011;18:273-81.

96. Mori M, Mimori K, Shiraishi T, Alder H, Inoue H, Tanaka Y, Sugimachi K, Huebner K, Croce CM. Altered expression of Fhit in carcinoma and precarcinomatous lesions of the esophagus. Cancer Res 2000;60:1177-82.

97. Xue HC, Wang JM, Xu B, Guo GP, Hua ZL, Zhou Q, Zhu ZH, Ma ZK, Gao J. Correlation of aberrant methylation of MGMT gene to MTHFR C677T genetic polymorphisms in esophageal squamous cell carcinoma. Ai Zheng 2008;27:1256-62.

98. Ling ZQ, Li P, Ge MH, Hu FJ, Fang XH, Dong ZM, Mao WM. Aberrant methylation of different DNA repair genes demonstrates distinct prognostic value for esophageal cancer. Dig Dis Sci 2011;56:2992-3004.

99. Schulmann K, Sterian A, Berki A, Yin J, Sato F, Xu Y, Olaru A, Wang S, Mori Y, Deacu E, Hamilton J, Kan T, Krasna MJ, Beer DG, Pepe MS, Abraham JM, Feng Z, Schmiegel W, Greenwald BD, Meltzer SJ. Inactivation of p16, RUNX3, and HPP1 occurs early in Barrett's-associated neoplastic progression and predicts progression risk. Oncogene 2005;24:4138-48.

100. Yao D, Shi J, Shi B, Wang N, Liu W, Zhang G, Ji M, Xu L, He N, Hou P. Quantitative assessment of gene methylation and their impact on clinical outcome in gastric cancer. Clin Chim Acta 2012;413:787-94.

101. Murai M, Toyota M, Suzuki H, Satoh A, Sasaki Y, Akino K, Ueno M, Takahashi F, Kusano M, Mita H, Yanagihara K, Endo T, Hinoda Y, Tokino T, Imai K. Aberrant methylation and silencing of the BNIP3 gene in colorectal and gastric cancer. Clin Cancer Res 2005;11:1021-7.

102. Yuasa Y, Nagasaki H, Akiyama Y, Hashimoto Y, Takizawa T, Kojima K, Kawano T, Sugihara K, Imai K, Nakachi K. DNA methylation status is inversely correlated with green tea intake and physical activity in gastric cancer patients. Int $J$ Cancer 2009;124:2677-82.

103. Ben Ayed-Guerfali D, Benhaj K, Khabir A, Abid M, Bayrouti MI, Sellami-Boudawara T, Gargouri A, Mokdad-Gargouri R. Hypermethylation of tumor-related genes in Tunisian patients with gastric carcinoma: clinical and biological significance. J Surg Oncol 2011;103:687-94.

104. Shi J, Zhang G, Yao D, Liu W, Wang N, Ji M, He N, Shi B, Hou P. Prognostic significance of aberrant gene methylation in gastric cancer. Am J Cancer Res 2012;2:116-29.

105. Jee CD, Kim MA, Jung EJ, Kim J, Kim WH. Identification of genes epigenetically silenced by $\mathrm{CpG}$ methylation in human gastric carcinoma. Eur J Cancer 2009;45:1282-93.

106. Peng DF, Hu TL, Schneider BG, Chen Z, Xu ZK, El-Rifai W. Silencing of glutathione peroxidase 3 through DNA hypermethylation is associated with lymph node metastasis in gastric carcinomas. PLoS One 2012;7:e46214.

107. Kongkham PN, Northcott PA, Ra YS, Nakahara Y, Mainprize TG, Croul SE, Smith CA, Taylor MD, Rutka JT. An epigenetic genome-wide screen identifies SPINT2 as a novel tumor suppressor gene in pediatric medulloblastoma. Cancer Res 2008;68:9945-53.

108. Wang L, Chen S, Xue M, Zhong J, Wang X, Gan L, Lam EK, Liu X, Zhang J, Zhou T, Yu J, Jin H, Si J. Homeobox D10 gene, a candidate tumor suppressor, is downregulated through promoter hypermethylation and associated with gastric carcinogenesis. Mol Med 2012;18:389-400.

109. Hibi K, Sakata M, Yokomizo K, Kitamura YH, Sakuraba K, 
Shirahata A, Goto T, Mizukami H, Saito M, Ishibashi K, Kigawa G, Nemoto H, Sanada Y. Methylation of the MGMT gene is frequently detected in advanced gastric carcinoma. Anticancer Res 2009;29:5053-5.

110. Kitajima Y, Ohtaka K, Mitsuno M, Tanaka M, Sato S, Nakafusa Y, Miyazaki K. Helicobacter pylori infection is an independent risk factor for Runx3 methylation in gastric cancer. Oncol Rep 2008;19:197-202.

111. Lu XX, Yu JL, Ying LS, Han J, Wang S, Yu QM, Wang XB, Fang XH, Ling ZQ. Stepwise cumulation of RUNX3 methylation mediated by Helicobacter pylori infection contributes to gastric carcinoma progression. Cancer 2012;118:5507-17.

112. Zou H, Harrington JJ, Shire AM, Rego RL, Wang L, Campbell ME, Oberg AL, Ahlquist DA. Highly methylated genes in colorectal neoplasia: implications for screening. Cancer Epidemiol Biomarkers Prev 2007;16:2686-96.

113. Ebert MP, Model F, Mooney S, Hale K, Lograsso J, Tonnes-Priddy L, Hoffmann J, Csepregi A, Rocken C, Molnar B, Schulz HU, Malfertheiner P, Lofton-Day C. Aristaless-like homeobox-4 gene methylation is a potential marker for colorectal adenocarcinomas. Gastroenterology 2006;131:1418-30.

114. Lee BB, Lee EJ, Jung EH, Chun HK, Chang DK, Song SY, Park J, Kim DH. Aberrant methylation of APC, MGMT, RASSF2A, and Wif-1 genes in plasma as a biomarker for early detection of colorectal cancer. Clin Cancer Res 2009;15:6185-91.

115. Ahlquist DA, Zou H, Domanico M, Mahoney DW, Yab TC, Taylor WR, Butz ML, Thibodeau SN, Rabeneck L, Paszat LF, Kinzler KW, Vogelstein B, Bjerregaard NC, Laurberg S, Sorensen HT, Berger BM, Lidgard GP. Next-generation stool DNA test accurately detects colorectal cancer and large adenomas. Gastroenterology 2012;142:248-56.

116. Ahlquist DA, Taylor WR, Mahoney DW, Zou H, Domanico M, Thibodeau SN, Boardman LA, Berger BM, Lidgard GP. The stool DNA test is more accurate than the plasma septin 9 test in detecting colorectal neoplasia. Clin Gastroenterol Hepatol 2012;10:272-7e1.

117. Yamaguchi S, Asao T, Nakamura J, Ide M, Kuwano H. High frequency of DAP-kinase gene promoter methylation in colorectal cancer specimens and its identification in serum. Cancer Lett 2003;194:99-105.

118. Hellebrekers DM, Lentjes MH, van den Bosch SM, Melotte V, Wouters KA, Daenen KL, Smits KM, Akiyama Y, Yuasa Y, Sanduleanu S, Khalid-de Bakker CA, Jonkers D, Weijenberg MP, Louwagie J, van Criekinge W, Carvalho B, Meijer GA, Baylin SB, Herman JG, de Bruine AP, van Engeland M. GATA4 and GATA5 are potential tumor suppressors and biomarkers in colorectal cancer. Clin Cancer Res 2009;15:3990-7.

119. Suzuki H, Igarashi S, Nojima M, Maruyama R, Yamamoto E, Kai M, Akashi H, Watanabe Y, Yamamoto H, Sasaki Y, Itoh F, Imai K, Sugai T, Shen L, Issa JP, Shinomura Y, Tokino T, Toyota M. IGFBP7 is a p53-responsive gene specifically silenced in colorectal cancer with $\mathrm{CpG}$ island methylator phenotype. Carcinogenesis 2010;31:342-9.

120. Melotte V, Lentjes MH, van den Bosch SM, Hellebrekers DM, de Hoon JP, Wouters KA, Daenen KL, Partouns-Hendriks IE, Stessels F, Louwagie J, Smits KM, Weijenberg MP, Sanduleanu S, Khalid-de Bakker CA, Oort FA, Meijer GA, Jonkers DM, Herman JG, de Bruine AP, van Engeland M.
N-Myc downstream-regulated gene 4 (NDRG4): a candidate tumor suppressor gene and potential biomarker for colorectal cancer. J Natl Cancer Inst 2009;101:916-27.

121. Herbst A, Rahmig K, Stieber P, Philipp A, Jung A, Ofner A, Crispin A, Neumann J, Lamerz R, Kolligs FT. Methylation of NEUROG1 in serum is a sensitive marker for the detection of early colorectal cancer. Am J Gastroenterol 2011;106:1110-8.

122. Zou H, Yu B, Zhao R, Wang Z, Cang H, Li D, Feng G, Yi J. Detection of aberrant p16 methylation in the serum of colorectal cancer patients. Zhonghua Yu Fang Yi Xue Za Zhi 2002;36:499-501.

123. Nagasaka T, Tanaka N, Cullings HM, Sun DS, Sasamoto H, Uchida T, Koi M, Nishida N, Naomoto Y, Boland CR, Matsubara N, Goel A. Analysis of fecal DNA methylation to detect gastrointestinal neoplasia. $J$ Natl Cancer Inst 2009;101:1244-58.

124. Tan SH, Ida H, Lau QC, Goh BC, Chieng WS, Loh M, Ito Y. Detection of promoter hypermethylation in serum samples of cancer patients by methylation-specific polymerase chain reaction for tumour suppressor genes including RUNX3. Oncol Rep 2007;18:1225-30.

125. Oh T, Kim N, Moon Y, Kim MS, Hoehn BD, Park CH, Kim TS, Kim NK, Chung HC, An S. Genome-wide identification and validation of a novel methylation biomarker, SDC2, for blood-based detection of colorectal cancer. J Mol Diagn 2013;15:498-507.

126. Li M, Chen WD, Papadopoulos N, Goodman SN, Bjerregaard NC, Laurberg S, Levin B, Juhl H, Arber N, Moinova H, Durkee K, Schmidt K, He Y, Diehl F, Velculescu VE, Zhou S, Diaz LA Jr, Kinzler KW, Markowitz SD, Vogelstein B. Sensitive digital quantification of DNA methylation in clinical samples. Nat Biotechnol 2009;27:858-63.

127. Ahn JB, Chung WB, Maeda O, Shin SJ, Kim HS, Chung HC, Kim NK, Issa JP. DNA methylation predicts recurrence from resected stage III proximal colon cancer. Cancer 2011;117:1847-54.

128. Wallner M, Herbst A, Behrens A, Crispin A, Stieber P, Goke B, Lamerz R, Kolligs FT. Methylation of serum DNA is an independent prognostic marker in colorectal cancer. Clin Cancer Res 2006;12:7347-52.

129. Katoh H, Yamashita K, Waraya M, Margalit O, Ooki A, Tamaki H, Sakagami H, Kokubo K, Sidransky D, Watanabe M. Epigenetic silencing of HOPX promotes cancer progression in colorectal cancer. Neoplasia 2012;14:559-71.

130. Jensen LH, Rasmussen AA, Byriel L, Kuramochi H, Cruger DG, Lindebjerg J, Danenberg PV, Jakobsen A, Danenberg K. Regulation of MLH1 mRNA and protein expression by promoter methylation in primary colorectal cancer: a descriptive and prognostic cancer marker study. Cell Oncol (Dordr) 2013;36:411-9.

131. Nilsson TK, Lof-Ohlin ZM, Sun XF. DNA methylation of the p14ARF, RASSF1A and APC1A genes as an independent prognostic factor in colorectal cancer patients. Int $J$ Oncol 2013;42:127-33.

132. Hibi K, Goto T, Shirahata A, Saito M, Kigawa G, Nemoto H, Sanada Y. Detection of TFPI2 methylation in the serum of colorectal cancer patients. Cancer Lett 2011;311:96-100.

133. Ogino S, Nosho K, Kirkner GJ, Kawasaki T, Chan AT, Schernhammer ES, Giovannucci EL, Fuchs CS. A cohort study of tumoral LINE-1 hypomethylation and prognosis in colon cancer. J Natl Cancer Inst 2008;100:1734-8. 